\title{
Between the Syriac heritage and the Papacy. The cultural influence and contribution of the Maronite Church to the growth of the Middle East in the $14^{\text {th }}-19^{\text {th }}$ centuries
}

The Maronites are proud of their Syriac roots and cultural connections with the West. ${ }^{1}$ The question arises: in what areas did the Syriac Christian community constitute a bridge between the East and the West? Although not all critical remarks of Kamāl Șalībī (b. 1929) on the Maronite view of history are accepted without reservation, his remark that "the awareness of the historic truth ( wa' $y$ al-haqīqa at-tārīhìya) constitutes the ultimate foundation for the possibility to build a healthy society"2 seems valuable. The postulate of the verification of over-interpretation is always valid, nevertheless the discussion: what is a myth (al-asâțīr) and what is the truth in the history of Lebanon continues. ${ }^{3}$

The analysis of the cultural heritage of the Maronites will let us establish to which degree the activities of the Maronites from the $15^{\text {th }}$ till the $19^{\text {th }}$ centuries prepared many processes in the Middle East in the modern times. The history

\footnotetext{
${ }^{1}$ See for example the statement of Yūnāna Abīda: ماهي علاقة الموارنة بالغرب؟

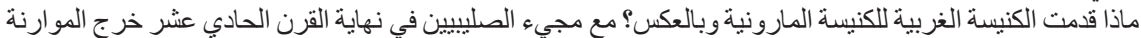

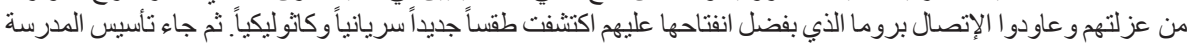

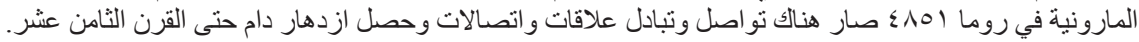

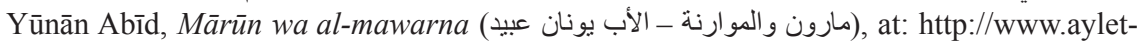
marcharbel.org/taalimgr16.htm [5.05.2010].

${ }^{2}$ K. Șalībī, Munțalaq at-tārīh Lubnān, Bayrūt 1979, p. 14.

${ }^{3}$ On the subject of the historical myths in the Lebanese tradition see: A. Beydoun, Identité confesionelle et temps social chez les historiens libanais contemporains, Beyrouth 1984; M. Kuderna, Christliche Gruppen im Libanon. Kampf um Ideologie und Herrschaft in einer unfertigen Nation, Wiesbaden 1984, pp. 185-204; K. Salibi, Islam and Syria in the Writings of Henri Lammens, [in:] Historians of the Middle East, ed. by B. Lewis, P. M. Holt, London 1962, pp. 330-342.
} 
of the community, originating from the Syriac Christians, at first concentrated around St. Maron's monastery, reflects the complicated religious situation in Syria and Lebanon after the Muslim conquests. ${ }^{4}$ During the Crusades the collaboration between the Maronites and the Latin Christians was very good. The Maronites entered the equestrian orders supporting them in their military actions, and in secular life they were on familiar terms with the European inhabitants of Syria. In the year 1181 the Maronite patriarch took the oath of faithfulness to the Pope before the Latin Patriarch of Antioch, Amaury of Limoges. This union was solemnly confirmed by the Fourth Lateran Council in 1215. Since that time the Maronite Church has remained in communion with the Catholic Church. In this context a special attention should be paid to the modern history of the Maronites, which for some time was the only Church that had strong cultural connections with the West. ${ }^{6}$

\section{The fruit of the collaboration between the Maronites and Rome in the context of fathoming the union}

The conquest of the last Frankish centres in Syria and Palestine by the Mamluks had serious consequences for the Maronites. Firstly, it is supposed that those who openly collaborated with the Crusaders left the territories of the Middle East and found shelter in Cyprus in fear of persecutions. Secondly, the Mamluks looked at the Jews and Monophysite Christians more favourably than the Maronites who were connected with the Latin Christians. The Latin hierarchy left the Middle East. The Latin Patriarch of Jerusalem Nicholas of Hanapes (1288-1291) was killed while escaping from Acre. His successors resided in Cyprus. ${ }^{7}$

${ }^{4}$ Cf. M. de Ghantuz Cubbe, "Quelques reflections à propos de l'histoire ancienne de l'Église maronite," Parole de l'Orient 26 (2001), pp. 3-69; K. S. Salibi, "The Maronites of Lebanon under Frankish and Mamluk Rule (1099-1516)," Arabica 4 (1957), pp. 288-303; H. Sürmann, Grundungsgeschichte der maronitischen Kirche, Wiesbaden 1998; L. van Rompay, The Maronites, [in:] G. Wainwright, K. B. Westerfield, The Oxford History of Christian Worship, Oxford 2006, pp. 170-172; R. A. Kitchen, Maronite Church, [in:] The New Westminster Dictionary of Church History. The Early, Medieval, and Reformation Eras, ed. by R. Benedetto, Luisville 2008, pp. 410-411.

${ }^{5} \mathrm{Cf}$. Bullarium Maronitarum: complectens bullas, brevia, epistolas, constitutiones aliaque documenta a Romanis pontificibus ad patriarchas Antiochenos Syro-Maronitarum missa; ex tabulario secreto S. Sedis, ed. by T. Anaissi, vol. 8, Romae 1911, p. 2.

${ }^{6}$ The very factography of the history of the Maronite community shows the uniquely original phenomenon of interaction within this Church, see, e.g., P. Dib, L'Église maronite: du XVI siècle à nos jours, Beyrouth 1973; Ch. Frazee, Catholics and Sultans. The Church and the Ottoman Empire 1453-1923, Cambridge 1983.

${ }^{7}$ With time the office of the Latin Patriarch of Jerusalem became an ordinary title until the pontificate of Pius IX (1846-1878). See E. Amann, Eglise de Jérusalem, [in:] Dictionnaire de théologie catholique, ed. by E. Vacant, vol. 8, Paris 1930, p. 1003. 
Cyprus became the shelter for the Crusaders and some Maronites, their base camp and protection of the communication tract. ${ }^{8}$ After the fall of the last Frankish ports along the Palestinian-Syrian coast the Crusaders from Cyprus attempted to regain the coasts of Palestine and Lebanon. Obviously, these actions complicated the Christian-Muslim relationships in the region and brought about serious consequences for the Maronites. Fearing the collaboration with the Franks the Mamluks ordered to destroy many Palestinian ports, such as Acre or Caesarea and to populate the Lebanese coast with Arab Muslims from the Syrian inland. The Maronites lost numerous churches; their vineyards were destroyed and they were pushed to the mountains. ${ }^{9}$ These activities of the Mamluks changed permanently the proportions of the population in the region for the Christians' disadvantage. ${ }^{10}$ As for Cyprus, the presence of the Maronite community was confirmed well from the year $1357 .{ }^{11}$

The initiatives of the Council of Florence concerning the union were not only directed to the Byzantine Orthodox Church but also to the Eastern Christians. On 29 June 1445 the Maronite Bishop of Cyprus Elias confirmed the faithfulness of the union ${ }^{12}$, for which the apostolic legate Andrew of Rhodes, OP, (died ca. 1458) $)^{13}$ did his best to happen. The Maronites of Cyprus might have preserved some elements of monoteletism, which disturbed Rome. ${ }^{14}$ The Maronite hierarchy in Cyprus played an important role in contacts with the West. For years Cyprus was an essential place of exchange of ideas. Considering its geographical, cultural and religious aspects it was as if "the space of two

${ }^{8}$ See more P. W. Edbury, The Kingdom of Cyprus and the Crusades, Cambridge 1991.

${ }^{9}$ One of the sources describing the dramas of the Mamluk epoch is the works of 'the father of the Maronite history' Istịānūs ad-Duwaihī (1630-1704), who included the following facts:

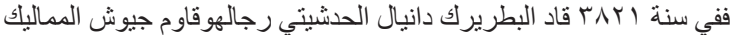

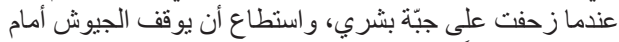

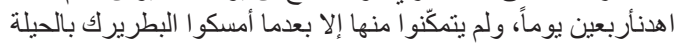

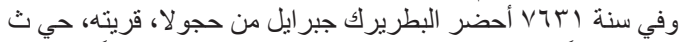

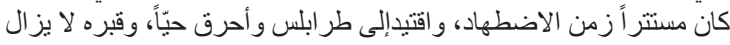

$$
\begin{aligned}
& \text { في باب الرمل في مدخل المدينة }
\end{aligned}
$$

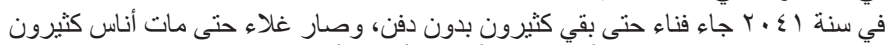

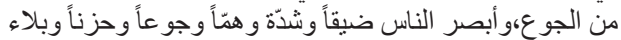

Isțifānūs ad-Duwaihī, Ta'rīh al-azmina, 1095-1699 m, ed. by F. Tautal, Bayrūt 1951, p. 338.

${ }^{10}$ Cf. M. Haji Athanasiou, Mawsū'a Batrīarkīya Anțākìya at-tārīhiyya wa al-ațariyya, vol. 6, Dimašq 2001, pp. 184-185, 195-196.

${ }^{11}$ Cf. G. Graf, Geschichte der christlischen arabischen Literatur, vol. 3, Vatican 1950, p. 42.

${ }^{12}$ Cf. Documenta Concilii Florentini de unione orientalium. Documenta iuxta fidem mss. coll. et notis illustr., ed. by G. Hofmann, Roma 1936, pp. 50-54.

${ }^{13} \mathrm{Cf}$. Genuinae relationes inter sedem Apostolicam et Assyriorum orientalium seu Chaldaerum ecclesiam: nunc majori ex parte primum editae historicisque adnotationibus illustratae, ed. by S. Giamil, Rome 1902, no. 3.

${ }^{14}$ Cf. G. Graf, Geschichte der christlischen arabischen Literatur, vol. 3, Vatican 1950, p. 42. 
worlds," multicultural reality that was extremely important to the contacts between the Oriental Christianity and the Papacy.

In turn, the Franciscan friar Gryphon (d. 1475) ${ }^{15}$ was very successful among the Maronites in Lebanon. The Franciscan sources write about an extraordinary zeal of this brother and his numerous efforts to deepen the Catholic faith among the Maronites. It will be difficult to give here the colourful story of Gryphon's life and the historians' disputes about the details of his mission. ${ }^{16}$ It seems that the biggest cultural fruit of his mission was Ğibrā'̄il ibn al-Qilā'̀̄ (d. 1516), the first modern writer of the Maronite Church, who entered the Franciscan Order, gained a thorough education in Rome and became the Maronite Bishop of Cyprus. Actually the writings of Ğibrā'îla ibn al-Qilā' 1 focused on theology and polemics with the Monophysites but they were pioneering in the background of his epoch. His Madīha 'alā ğabal Lubnān is a wonderful epos from the mountains of Lebanon. ${ }^{17}$ At the same time it is a work focusing on the Maronites as Lebanon's centre of gravity, a work that praises their ethos and importance.

The number of the preserved testimonies confirming regular contacts between the Maronites and Rome decisively increased from the second half of the $15^{\text {th }}$ century. These documents testify to the intensification of mutual contacts and show an original union of openness and concern for preserving their Syriac tradition. On the one hand, the contacts with the West inspired new ecclesiastical and cultural solutions and on the other hand, did not destroy the traditional position of the patriarch. It is worth remembering that for the Maronites the patriarch has been a figure who is far more than a legal leader of the Church. He constitutes the epitome of the Maronites' history and identity. This phenomenon has involved several elements. The Maronite Church was shaped around her monasteries. This model differed from the Latin model based on the structure of the metropolitan where the bishop and his auxiliaries reflected in some sense the secular administrative structures of the Roman state. For the Maronites their patriarch was initially the most important abbot patronising the federation of monasteries and then the only religious leader of his people. The bishops-abbots of particular monasteries were only the representatives of the patriarch. The position of the patriarch was also strengthened by the Muslims, among whom the Maronites had to live. Especially, the Ottoman system of the millets strengthened the right of the patriarch to be the spiritual and political leader of the community. The patriarch was responsible for both religious

${ }^{15}$ The Maronites had good relationships with the Franciscans from the year 1246.

${ }^{16}$ Cf. M. Moosa, The Maronites in History, Syracuse 2005, pp. 233-240; H. Lammens, "Fr. Gryphon et le Liban au XVe siècle," Revue de l'Orient Chrétienne 4 (1899), pp. 68-104.

${ }^{17}$ Cf. K. Salibi, The Maronite Historians of Medieval Lebanon, Beirut 1959, pp. 35-37; K. Salibi, The Traditional Historiography of the Maronites, in: Historians of the Middle East, ed. by B. Lewis, P. M. Holt, London 1962, pp. 212-225. 
and civil life of his subjects. He was responsible for their behaviours, having administrative and judicial prerogatives as far as the marriage and heritage laws were concerned. He supervised the whole properties of the Church; he was the highest instance in the Maronites' ecclesiastical and civil matters. ${ }^{18}$ Commencing from 1445 the Maronite patriarchs usually resided in the monastery of Qannūbīn.

The Fifth Council of Lateran (1512-1517) strengthened the union of the Maronites with Rome. ${ }^{19}$ In turn in the epoch of implementation of the decrees of the Council of Trent (1545-1563) the popes tried to put the new structural solutions systematically into the old order. The regulations of the Congregation Propaganda fidei from the years 1625 and 1635 established canonical dioceses but fundamentally they functioned according to the traditional solutions until the year 1736 .

The final seal of the union was the mission of Giovanni Battista Eliano in the years $1578-1580^{20}$ during the times of Pope Gregory XIII (1572-1585) and the initiatives of the Maronite Patriarch Michael Peter ar-Ruzziego (1567-1581) together with the synod in Qannūbīn held on 15-17 August 1580. The next years brought about closer relationships and Latinisation of the Maronite Church, which resulted in accepting the Gregorian calendar in 1606 by Patriarch Joseph ar-Ruzzī (1597-1608).

${ }^{18}$ Cf. M. Moosa, The Maronites in History..., 2; I. Aoud, Le droit privé des Maronite au temps des Émirs Chihab (1697-1841), Paris 1933. Mehmed II the Conquerer (1432-1481), who appointed the Ordothox patriarch as the civilian leader of all Ordodox believers, the Armenian patriarch as the head of the Armenians and appointed the main Rabbi for the Jewish communities, is regarded as the creator of the millet system. With time other communities, including the Maronites, joined the millets. The system included a quasi-sovereign secular authority in judicial, tax and financial matters over the subordinated "nation." The religious communities were called "nations," which was equivalent to the circles of believers as in the case of the Armenian Church. In turn the Patriarch of Constantinople and the Patriarch of Antioch were recognised as the rulers of the imagined rum millet - "Roman nation," which allowed their functioning in the Ottoman system. Cf. K. Kościelniak, Organizacja, kondycja i problemy mniejszości religijnych w Turcji, [in:] Państwo, wspólnota i religia, pod red. K. Kościelniaka, Kraków 2010, p. 250; M. Alan, Christian and Jews in the Ottoman Empire: the Roots of Sectarianism, New York 2001, pp. 130-199; A. Özcan, The Ottoman Millet System, [in:] Islam in the Middle Eastern studies. Muslims and minorities, ed. by U. Akira, K. Hiroshi, Osaka 2003, pp. 225-230; T. Küçükcan, "State, Islam and Religious Liberty in Modern Turkey. Reconfiguration of Religion in the Public Sphere," Brigham Young University Law Review 2 (2003), pp. 475-480; I. Yildiz, "Minority rights in Turkey," Brigham Young University Law Review 3 (2007), pp. 791-792.

${ }^{19}$ Cf. B. Ghobaira al-Ghaziri, Rome et l'Église Syrienne-Maronite d'Antioche (517-1531), Beyrouth 1906.

${ }^{20}$ Cf. T. Anaissi, Collectio documentorum Maronitarum, Liburni 1921, pp. 56-61. 


\section{New identity at the crossing of the Syriac and Latin traditions}

The new identity of the modern times was shaped by outstanding personalities as well as by certain processes and tendencies.

As for the personalities, the most famous and important Maronite patriarch of the modern times until the $19^{\text {th }}$ century was Isțifānūs ad-Duwaihī (1670-1704 (البطريرك إسطفانوس الدويهي . One can say that he returned the Maronites their history. With admirable stubbornness he reminded the Maronites of their Syriac roots, at the same time being a fervent advocate of the union and closer contacts with Rome. No wonder, the Maronite historiography gave him many titles such as "holy patriarch," "the father of the Maronite history," "the pillar of the Maronite Church," "second Chrysostome," "splendour of the Maronite nation," "glory of Lebanon and the Maronites." ${ }^{21}$ At the age of eleven Isțifān ad-Duwaihī went to Rome where he studied in the Maronite College. He was fluent in Arabic, Syriac, Italian, Latin, Greek and Hebrew. He spoke good Turkish and French. Despite the proposal to be a professor in Rome he returned to Lebanon in 1656 and was ordained priest in St. Sergius' and Bacchus' monastery in Ehden. In 1657 he began working among the Syriac Christians in Aleppo, laying foundations of the Uniate Syriac-Catholic Church. In 1668 he became the Bishop of Cyprus and in 1670 the Maronite Patriarch. He initiated the construction of 27 churches; ordained 14 bishops and as an advocate of the union he used the Roman patterns, e.g. in the reforms of religious orders. At the same time - which should be stressed - he defended his community against an excessive Latinisation. For many he remained a statesman, an example of openness and faithfulness to the tradition. Despite his numerous travels, forced by the turbulent Ottoman times, he wrote exceptionally many works about the history and liturgy of the Syriac heritage.${ }^{22} \mathrm{He}$ had an extremely extensive correspondence with the popes, cardinals, kings and Ottoman officials. ${ }^{23}$ First of all, one should mention his

${ }^{21}$ This patriarch has many new appreciative terms:

$$
\begin{aligned}
& \text { لم يقم عند الموارنة مثل الدويهي عالم غيور على ملّتّه }
\end{aligned}
$$

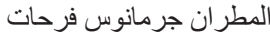

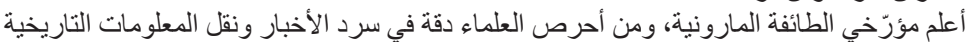

$$
\begin{aligned}
& \text { الأب مرتين اليسو عي الطياتية اليار }
\end{aligned}
$$

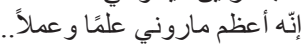

$$
\begin{aligned}
& \text { المطر ان بطرس شبلي }
\end{aligned}
$$

Cf. البطريرك إسطفان الدويهي, http://www.ecu-lb.com/ptrk/makt.php?subaction=showfull\&id=1 $116226404 \&$ archive $=\&$ start_from $=\& u c a t=7 \&$ [5.05.2010].

${ }^{22}$ For example, The Syriac model strophes and their poetic meters, Stefan ad-Duwaihī, Louis Hage, Kaslik 1987.

${ }^{23}$ Cf. المكرّم البطريرك إسطفانوس ميخائيل الدويهي (1704-1630), at: www.choumafi.com/articles. php?art_id=39\&start=1; I. Sadek, Patriarch Stefan Duwayhi, his Life and his Times, at: http:// ddata.over-blog.com/1/93/30/42/index.htm [4.05.2010]. 
works that deepened the Syriac identity of the Maronites in the context of the union, e.g., Tārīh at -țā'ifa al-mārūnìya. ${ }^{24}$ Isțifānūs ad-Duwaihī can be said to have created a concentric world consisting of three circles: the Maronites, Great Syria and the world of Islam.

It has already been mentioned that the new identity of the Maronites was created by certain processes, interactions with the Western Church. The first one was the evolution and enrichment of the understanding of patriarch, bishopric and nature of the Church. It is worth reminding that the exodus of the Maronites in the $8^{\text {th }}$ century led to break contacts with the Melkite (Catholic) Patriarch of Antioch and in some unknown circumstances the Maronite community created their own independent hierarchy with their patriarch as the head, having the title of "Patriarch of Antioch." This fact entangled the Maronites into many conflicts with the Melkite-Catholics and Orthodox Catholics and is still creating problems in the interpretation of the history of this delicate period. It is worth remembering that because of the divisions of the Oriental Churches the title of Patriarch of Antioch is carried by several hierarchs among whom the Patriarch of the Syriac Orthodox Church lays special claims. ${ }^{25}$ In his history Isțifānūs adDuwaihī recognised St. Maron as a monk and superior of the monastery but first of all, as the first Maronite patriarch, ${ }^{26}$ who began the uninterrupted line of the Maronite patriarchs. Regardless of the interpretation, the Maronite patriarch, as the highest shepherd, together with the monasteries subordinate to him created a quasi state in Lebanon. The bishops who were subordinate to the patriarch were still monks leading religious lives according to their rules. This strong

${ }^{24}$ Cf. Isțifān ad-Duwaihī, Tārīh at-țā'ifa al-mārūnīya, ed. by Rašīd al-Hูūrī aš-Šartūnī, Bayrūt 1890.

${ }^{25}$ Cf. R. French, The Eastern Orthodox Church, London 1951; A. Fortescue, The Orthodox Eastern Church, London 1920. See various aspects of this issue in: M. Moosa, The Maronites in History..., 57-58; 223; 229, 316, 332, 348; 350; 355.

${ }^{26} \mathrm{Cf}$. Istifānūs ad-Duwaihī, Ta'rīh al-azmina ...,pp. 50-51. It is worth seeing the contemporary official views of the Maronites on this issue. See, e.g., the justification of the Maronite patriarchate:

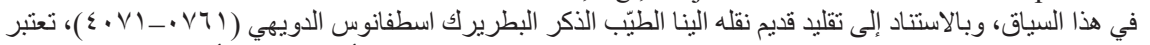

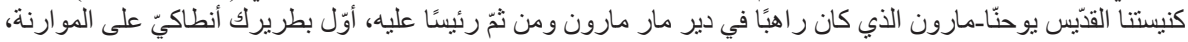

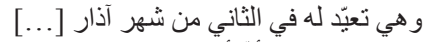

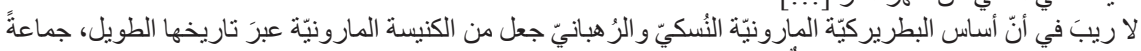

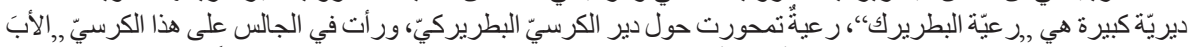

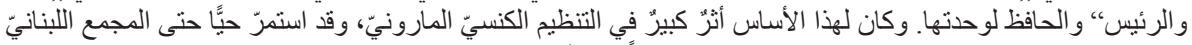

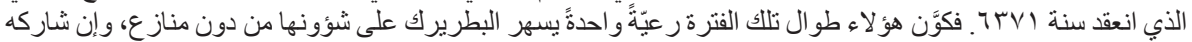

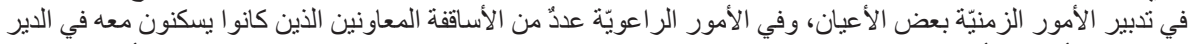

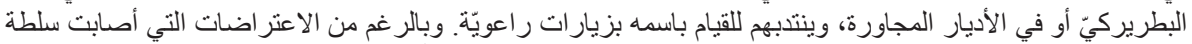

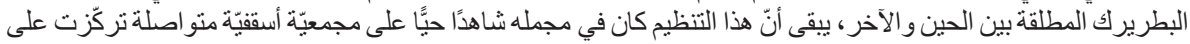

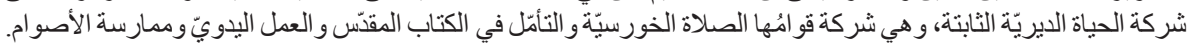

See كنيسة بطريركيّة ذات طابع نسكيّ ور هبانيّ النيّة php?option=com_content\&view $=$ article \&id=59:2008-07-01-15-55-09\&catid=35:2008-0701-13-08-59\&Itemid=55 [26.04.2010]. 
connection between the bishopric and monasticism evolved under the influence of the Western Church, especially after the foundation of the Maronite College in Rome in 1584. ${ }^{27}$ The influence of the West led to the legislation according to which a bishop must be a celibatist: a monk or diocesan priest. Regardless of these changes the Maronite ritual of bishop's ordination has preserved the ceremony to put on a religious robe (a hood) for those who are not monks.

Undoubtedly, the monastic and ascetic Maronite traditions constitute the Maronite Church as if on the pattern of "patriarchal parish" in which the patriarch is the father and head of the community and guarantee of its unity. Till 1736 the patriarch had only one order and there were also auxiliary bishops in his monastery (sometimes in the neighbouring monasteries). The patriarch sent them as his delegates to visit all monasteries and communities of the Maronites. Despite some rare cases of opposition against the absolute authority of the monk-patriarch the system in question generated the dynamic and efficiently functioning episcopate, constantly formed by common prayers, meditations, work and mortifications.

The Maronite Church preserved this structure until the Council of Lebanon in the year 1736. The fathers of this assembly - rightly described as "Lebanese Council of Trent" ${ }^{28}$ by Anne Françoise Weber - having the big support of Rome made an administrative division of the territories inhabited by the Maronites in Lebanon into eight eparchies (bishoprics). In the year 1834 they were reduced to seven. ${ }^{29}$ The council obliged the bishops to reside in their dioceses. The reform was implemented cautiously and was opposed by some monks. They saw it as a threat for the unity of the Maronite Church and her traditional structure of gathering around "the main shepherd," which was always the strength of that Syriac Christian group. ${ }^{30}$ Today, three ages after these events, the Maronite Church is a community of two experiences: synodal system and the old "religious rhythm." The latter becomes the spiritual and political power

${ }^{27}$ Cf. R. Herzstein, "The Foundation of the Saint-Joseph University of Beirut. The teaching of the Maronites by the Second Jesuit Mission in the Levant," Middle Eastern Studies 43 (2007), pp. 749-759.

${ }^{28}$ Cf. A.F. Weber, "Le Synode Libanais de 1736," Archives de sciences sociales des religions 122 (2003), p. 134, document no. 122.56.

${ }^{29}$ Cf. S. Huațāâr ad-Daḥdāḥ, "Die maronitischen Diözesen und die Liste ihrer Bischöfe," Mašriq 7 (1904), the Diocese of Baalbek, pp. 641-647; the Diocese of Damascus, pp. 748-755; the Diocese of Cyprus, pp. 1022-1029; the Diocese of Beirut, pp. 1099-1105; S. Hatțār ad-Daḥdāḥ, "Die maronitischen Diözesen und die Liste ihrer Bischöfe," Mašriq 8 (1904): the Diocese of Tyre and Sidon, pp. 151-154; the Diocese of Tripoli, pp. 401-407; the Diocese of Aleppo, pp. 407-409.

${ }^{30}$ Cf. E. Atallah, Le Synode Libanais de 1736, vol. 1: Son influence sur la restructuration de l'Église maronite, Antélias 2001, vol. 2: Traduction du texte original arabe, Antélias 2002; N. Gemayel, Les Échanges Culturels Entre les Maronites et l'Europe: Du Collège Maronite de Rome 1584 au Collège de 'Ayn-Warka 1789, Beirut 1984, p. 188. 
of the Maronites in every Lebanese crisis. Moreover, the "religious rhythm" paradoxically seems to strengthen the synodal spirit. ${ }^{31}$

The Maronites are sometimes accused of losing their Syriac tradition as the result of the synod of $1736 .{ }^{32}$ It seems that this thesis - decisively rejected by the Maronites - is not true. For instance, the above-mentioned synod stressed that the first language of the Maronites is Syriac although it was not used in everyday life at all. Arabic was regarded as the second language. The Maronite liturgy, although arabicised, is basically the ancient version of the Syriac liturgy of St. James, being the liturgy of the Church of Antioch. The liturgy was enriched with some Western elements. What can be called "divergence" on the one hand, is called "richness" on the other hand. One should also refer to the connection with the Papacy. The union with the Roman Church has been described as the foundation of the identity and mission of the Maronite Church. ${ }^{33}$ In fact, the union has never caused firm divisions or splits of the Maronite community. ${ }^{34}$ That's why the Maronites have been the support and creators of unions with other Oriental Churches to some extent.

A new view of the role of religious orders was another dimension of the processes influencing the evolution of the Maronites' identity. The above-discussed changes that the religious organisation does not cover the structures of the diocese brought about a profound reform of monasticism, which transformed its monolithic model into pluralistic religious life in the Maronite Church commencing

${ }^{31}$ The official explaination of the role of patriarch on the webpage of the Maronite Patriarchate testifies to that:

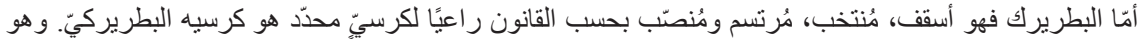

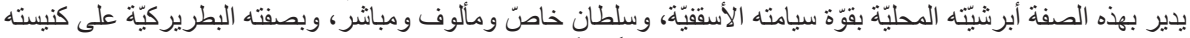

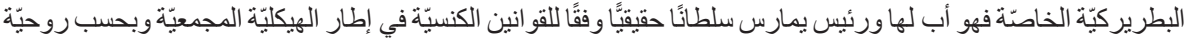

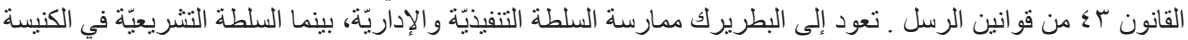

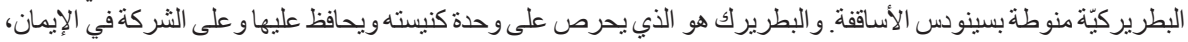

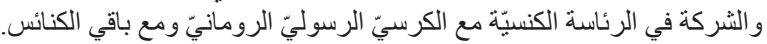

Hawla al-batrīarkiyya al-mārūniyya, at: http://bkerkelb.org/arabic/index.php?option=com_co ntent\&view=article\&id=77\&Itemid=62 [6.05.2010].

${ }^{32}$ Cf. M. Moosa, The Maronites in History..., p. 275.

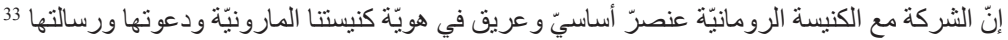

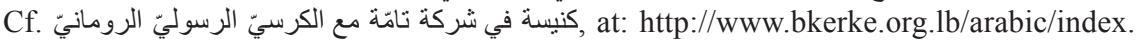
php?option=com_content\&view=article\&id=58:2008-07-01-15-46-32\&catid=35:2008-07-0113-08-59\&Itemid $=55$ [28.04.2010].

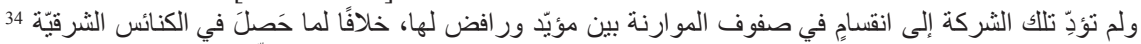

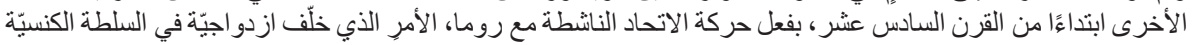

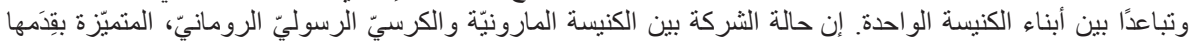

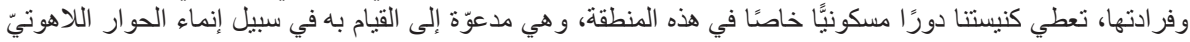

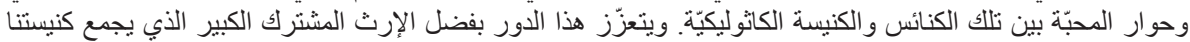

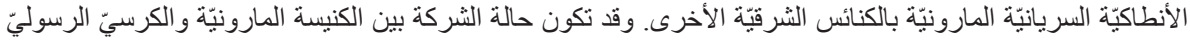

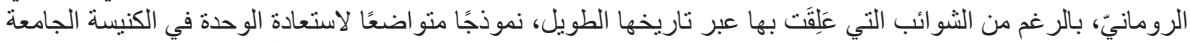

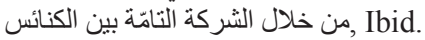


from the $17^{\text {th }}$ century. Such a solution was forced by the Maronite reality and the arrival of the Roman orders and congregations, such as the Franciscans, the Jesuits, the Sisters of Charity, the Salesians of John Bosco and many others. For the last several centuries these interactions have led to new attempts to reconcile the spirituality of the East with the Western models of organisation. The most striking fact in the contemporary Lebanese religious organisation is that all orders, rules, reforms and changes are confirmed by the Apostolic See after the prior approval of the patriarch. All these elements have led to the existence of orders on the pontifical and diocesan laws as they are in Europe. Despite the cultural-political tensions, which always appear in the context of religious reforms, the Maronite theologians stress that the reforms of their Church have come at the best time and in the original forms. The faithfulness to the successor of St. Peter in the person of the Pope, which is the condition of abiding fully in the Catholic Church, does not contradict the patriarchal Church being a part of the universal Church. Furthermore, according to the vision of the Church defined by Vatican Council II it is completely justified that the local Churches, especially the Oriental Churches, have their "particular law" within the universal Church because of their honourable tradition and significance.

\section{The merits in the modernisation of the Middle East: education and publishing houses}

The first Maronite who gained a profound education in the west was Ğibrā'̄1 ibn al-Qilā' $\mathbf{1}$. This was made possible thanks to the fact that the province Terra Santa belonged to the Franciscan Order. In the next decade one of the custodians of the Holy Land Francesco Suriano (1493-1495 and 1512-1515) ${ }^{35}$, ending his work in the custody, having the fervent support of the Maronite patriarch Simon al-Hadatī (1492-1524) took with him one diocesan priest and two Maronite monks to Rome in 1515. In turn Patriarch Michael Butrus ar-Ruzzī (1567-1581), through the custodian of Terra Santa, asked Pope St. Pius V (1566-1572) to make available some building in Rome in order to found a college for young Christians from the Middle East. The above-mentioned apostolic legate Giovanni Battista Eliano brought some young Maronites, who wanted to study in Rome, from his three missions to the East. It is worth adding that Patriarch Michael Butrus ar-Ruzzī wanted to found such a college in Cyprus but his plan was made impossible by the conquest of the island by the Ottoman Turks in 1571 . In the year 1583 Pope Gregory XIII (1572-1585) offered the Maronites a house in the centre of Trevi, which was changed into a college a year later. The generous financial support of the Pope and Cardinal Antonio Carafa (1531-1598)

${ }^{35}$ A. Arce, Maronitas y Franciscanos nn El Libano 1450-1516, [in:] In Miscelánea De Tierra Santa, vol. 2, Jerusalem 1973, p. 253. 
made the school a good scientific unit. However, the history of the school was turbulent. From 1583 to 1773 the Maronite College was run by the Jesuits until the famous breve Dominus ac Redemptor of Pope Clement XIV (1769-1774), liquidating the Jesuit order. Then the formation of the Maronites was given to the diocesan clergy. After the conquest of Rome by the French in 1798 the Maronite College was confiscated and its large part was sold in 1808. When the Church state was restored in 1815 Propaganda fidei began educating the Maronites with other candidates in the college. The efforts of Patriarch Jusuf Hubaiša (1823-1845) to regain the building of the Maronite College failed. But thanks to the great determination of Patriarch Bulus Mas'ada (1854-1890) and the Maronite Episcopate sufficient means were collected to open a new Maronite college, which was confirmed on 30 November 1890 by Pope Leo XIII (1878-1903). The first rector of the new college, opened in 1897, was the titular bishop of Acre, later Patriarch Elias Huwaika (1898-1931).

The Roman Maronite College gave Lebanon a big number of educated Christians, among from which patriarchs, bishops and writers were recruited ad they contributed to the development of contacts with the West and widening of the intellectual horizons of the Lebanese. These contacts inspired the Maronite Church to create local schools. For example, in 1789 Patriarch Jusuf Isțifānūs founded a theological school in 'Ain Warana, which was then reformed by Patriarch Jusu At-Taiyān (1796-1809) enlarging its educational offer with languages, literature, philosophy and law. Thanks to the monastery library precious literary works and manuscripts were gathered. Several diocesan schools were also created: Mār 'Abdā Harharīya, Mār Sarkīs Raifūn, 'Ain Sa'ada or the school called "college of knowledge," opened in 1875 in the residence of Bishop Jusufa Ilyāsa of Beirut, which was a big achievement of the Maronite community.

As for the new local publications, Lebanon owes the Maronites the opening of the first printing houses. In 1610 in the monastery Quzhaiyā a psaltery containing Syriac and Arabic texts was printed. Towards the end of the $18^{\text {th }}$ another printing house was opened in the monastery of St. Moses, founded by the monk Hauqā aš-Šūsānī (d. 1814). Syriac texts were made there. In 1855 the congregation of the monastery Quzhaiyā created new printing workshops in Țamīs. From the middle of the $19^{\text {th }}$ century numerous printing houses opened in the whole Middle East. The Maronites excelled in producing books, having several printing houses. Towards the end of the $19^{\text {th }}$ century they were modernised and joined in one big printing house in Beirut.

$*$

It is worth summarising the research and answers to the posed question: in what areas do the Maronites constitute a bridge between the East and the West, contributing to the development of the Orient? 
Firstly, the Maronites were the first to show the necessity of the Western education and contacts in the epoch of modern Middle East. As Bernard Lewis states at the threshold of modern times the Muslims rooted a specific and dangerous view of the world and themselves. Medieval Europe was treated as unattractive and in some ways it was a disciple of the world of Islam, e.g., being forced to use the Arabic versions of the Greek works. But from the $14^{\text {th }}$ century the situation changed diametrically and there was a big civilisational progress in Europe. In modern times the Europeans surpassed the world of Islam a lot, leaving far behind its scientific, cultural and technological heritage. For ages, basically from the second half of the $18^{\text {th }}$ century, the Muslims were unaware of that fact. During that period only one Western book was translated into Turkish. The Maronites, firstly thanks to their contacts with the Franciscans and then the Maronite College in Rome, were the only group in the Middle East that gained profound education. They brought with them to the Orient the initiatives that dynamised the society, such as schools, printing houses and teaching of languages.

Secondly, thanks to the awareness of their history and identity born under the Western influence, the Maronites contributed to the decentralisation of the Ottoman provinces. Their contacts with the West and the help of the European powers, especially France, led to the promulgation of the organic statute of 1864 thanks to which the political and military control of the Ottoman Turkey over Lebanon was limited to a large extent. In the territories of Little Lebanon the centrifugal tendencies aiming at bigger autonomy or even independence became stronger. ${ }^{36}$ It was a specific pattern for state organisms that were created after the complete fall of Turkey at the end of World War I.

Thirdly, the contacts with the West brought about the restoration of the proper place of the Christian community in the Middle East, especially in Lebanon, which resulted in the cultural and economic growth of the region. In the $19^{\text {th }}$ century Beirut was the second biggest port of the Ottoman Empire.

On the other hand, the confessionalism of Lebanon, i.e. strict division of mandates many a time provoked quarrels or attempts of particular groups to gain the biggest possible influences in the regions. But it consolidated the division of society in the name of unity. ${ }^{37}$

${ }^{36}$ Which yielded the fruit of connection between the Lebanese institutions and the Arab nationalism in some social circles. More information in: P. Rondot, "Lebanese Institutions and Arab Nationalism,” Journal of Contemporary History 3 (1968) no. 3, pp. 37-51.

${ }^{37}$ The situation that Gerhard Lehmbruch called „Konkordanzdemokratie” (consociational democracy). Its features are: "fragmentarisation of subcultures," which can be religious or social communities, and the big role of the elite of those "subcultures." The author includes the case of Lebanon after 1860 sa an example for his thesis. Cf. G. Lehmbruch, Das konkordanzdemokratische Modell in der vergleichenden Analyse politischer Systeme, [in:] Politischer Wandel in konkordanzdemokratischen System. Symposium des Lichtenstein-Instituts 23-25 November 1989, hrsg. von H. Michalsky, Vaduz 1991, pp. 13-24. 
The beginnings of Lebanon's reform were connected with the departures and returns of the Maronites to their homeland. Despite the tragedy of 1860 , the contacts succeeded in 1864, which was the final breakthrough in Lebanon's democratisation. The events of 1860 , although they divided the local community, mobilised them to create a united society of Lebanon. There was a desire to heal the wounds without which one cannot speak of development. Règlement of 1864 crystallised the principle of co-existence of various groups, among other things through representatives of all communities on different levels of authority ${ }^{38}$ It also seems that it was the Lebanese Règlement that was a pattern for the Ottoman Constitution of 1876 to a considerable extent. ${ }^{39}$ Therefore, the self-awareness of the Maronites accelerated the modernising processes in the Middle East although like all phenomena they sometimes have ambivalent faces.

${ }^{38}$ Cf. E. Rabbath, La formation historique du Liban politique et constitutionnel, Beyrouth 1970, p. 377.

${ }^{39}$ On the democratisation of the structures of the Ottoman Turkey, see H. Kayali, "Elections and Electoral Process in the Ottoman Empire 1876-1919," International Journal of Middle East Studies 27 (1995), pp. 265-286. 
